\title{
Noise Levels in Markets in Ibadan, South West Nigeria
}

\author{
MKC Sridhar ${ }^{1 *}$ and FO Omokhodion ${ }^{2}$ \\ ${ }^{1}$ Department of Environmental Health Sciences, University of Ibadan, Ibadan \\ ${ }^{2}$ Department of Community Medicine, University of Ibadan, Ibadan
}

Submission: September 16, 2017; Published: October 27, 2017

*Corresponding author: MKC Sridhar, Department of Environmental Health Sciences, University of Ibadan, Ibadan, Email: mkcsridhar@gmail.com

\section{Introduction}

Markets in developing countries serve as vital socioeconomic institutions. Their level of activities often reflects the prosperity of the country. Ibadan is now regarded as the second largest city in Black Africa next only to Lagos Metropolis. Much of the commercial activities in the city take place in the traditional markets within residential premises. The number of markets in the city have grown from 26 in 1972, 36 in 1985 and to about 47 by 1994 . While these are well established, there are numerous other sites where selling and buying take place as the 'Yoruba' ethnic group, which is predominant in the city, are shrewd traders by tradition. The types of market stalls vary in Ibadan and they include: covered and lockable stalls, open stalls, open trading units with tables, and sale 'counters'.

The number of market stalls range from less than 100 (at Ijokodo area), to well over 5000 stalls at Dugbe and Gbagi areas Vagale [1], Filani \& Iyun [2]. The quality of physical environment in the city markets is generally deplorable with the exception of a few newly built markets. Amenities such as water supply, toilet facilities and waste disposal are poor but access by road is reasonably adequate. Most of the major roads are open to them thereby exposing them to noise and vehicular emissions. Markets in the indigenous or traditional areas are always crowded and going by foot is more convenient.

In recent years it is being realized that noise does not have to be loud to cause health problems. There is increasing evidence that exposure to relatively low levels of noise for long periods can affect health, raising blood pressure, disrupting cognitive development in children, disturbing sleep and prompting psychiatric disorders Anon [3]. The data on noise levels in Nigerian urban centers is very limited and no information is available among the markets in particular, which are wide spread among the residential areas all over the city. This paper describes noise levels in various markets areas in Ibadan city, identification of locations where the noise levels are above the permissible limits, and the activities that contribute to such higher levels.

\section{Materials and Methods}

There are about 47 major markets in Ibadan city. These markets are of five types depending on the time of operation:

a. Morning markets-held between 5.00AM and 12Noon and sell perishable goods such as vegetables and fruits.

b. Day markets most common in Yoruba tradition and operate between 8AM and 7PM; characterized by very intensive commercial activities with high density of population, congestion and noise.

c. Night markets - operate between 5PM and 10.00PM and specialize in selling various cooked foods; urbanization, however, has drastically reduced these types.

d. Day and Night markets function between 8.00AM and $10.00 \mathrm{PM}$ and they deal with a variety of commodities.

e. Periodic markets - held at intervals of 5 to 17 days during daytime; people from various nearby towns come and exhibit indigenous goods for sale.

Out of these, 22 were selected by random sampling. Night markets were not included in the study as they mostly deal with food items. Every market was visited during the peak period between $10 \mathrm{AM}$ and $2 \mathrm{PM}$ on working days. The sound levels were measured using CEL-269 Digital Integrating Sound Level Meter made in UK by CEL Instruments. At every point several readings, generally not less than three were taken and mean values and standard deviations were calculated before presenting in Tables.

\section{Results}

The noise levels in various markets are presented in Table 1. The results indicate that the lowest mean noise level was $58.7 \mathrm{~dB}$ 
in Railway yard and New Gbagi markets. The highest levels of 88.13dB were recorded in plank section of Bodija market, which is the largest in the city. However, the ranges recorded $47 \mathrm{~dB}$ as the lowest at the Cocoa House complex and a maximum of
$100 \mathrm{~dB}$ at slaughter slab area of cow section in Bodija market and electronic section of Agbeni market. These two markets are highly crowded at all times. The noise was mostly due to chatting and loud music.

Table 1: Noise levels in various markets under study.

\begin{tabular}{|c|c|c|c|c|}
\hline Market & Year of Establishment & Number of Stalls & $\begin{array}{c}\text { Noise level, } \\
\text { (Range, dB (A)) }\end{array}$ & $\begin{array}{c}\text { Noise Level } \\
(\text { Mean } \pm \text { SD, dB (A)) }\end{array}$ \\
\hline Bodija & 1987 & 2795 & & \\
\hline Cow section & - & - & 61-100 (n=15) & $74.90 \pm 10.4$ \\
\hline Plank section & - & - & $72-97(n=15)$ & $88.13 \pm 9.5$ \\
\hline Vegetable section & & & $65-90(n=19)$ & $78.70 \pm 8.2$ \\
\hline Construction site & 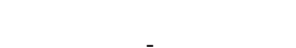 & 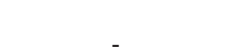 & $55-97(n=6)$ & $79.80 \pm 18.1$ \\
\hline Maior road at the market & 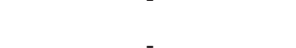 & 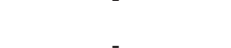 & $65-89(n=10)$ & $75.80 \pm 7.7$ \\
\hline 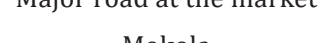 & 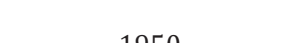 &  & $54-83(n=16)$ & $66.3 \pm 6.9$ \\
\hline Mokola & 1950 & 997 & $52-85(n=18)$ & $64.7 \pm 12.7$ \\
\hline Sabo & 1950 & 305 & $53-84(n=20)$ & $63.1 \pm 8.3$ \\
\hline Aleshinloye & 1990 & 1596 & $50-100(n=26)$ & $65.1 \pm 12.3$ \\
\hline Agbeni & 1950 & 4007 & $50-75(n=8)$ & $65.4 \pm 9.6$ \\
\hline Oje (fruit market) & 1860 & 2741 & $54-74(n=12)$ & $63.0 \pm 5.9$ \\
\hline Agodi Gate & 1968 & 3197 & $54-62(n=11)$ & $58.7 \pm 3.3$ \\
\hline New Gbagi & 1989 & 2853 & $68-85(n=9)$ & $77.9 \pm 5.1$ \\
\hline Oja-Oba & 1972 & -- & $60-78(n=13)$ & $66.6 \pm 7.3$ \\
\hline Iwo Road & -- & -- & $60-99(n=54)$ & $72.54 \pm 8.5$ \\
\hline Faleye (Automobile parts) & -- & -- & $58-77(n=11)$ & $67.1 \pm 5.8$ \\
\hline Challenge & 1977 & 314 & $61-78(n=7)$ & $68.9 \pm 5.7$ \\
\hline Ring Road & -- & -- & $66-86(n=9)$ & $76.0 \pm 5.9$ \\
\hline Apata & 1950 & 881 & $65-95(n=21)$ & $74.9 \pm 8.9$ \\
\hline Ojo & 1950 & 2752 & $60-88(n=16$ & $72.9 \pm 8.1)$ \\
\hline Shasha & 1975 & 2853 & $47-75(n=20)$ & $65.3 \pm 7.4$ \\
\hline Cocoa House Complex & 1960 & -- & $63-70(n=9)$ & $66.9 \pm 2.4$ \\
\hline AG Leventis Supermarket & -- & Single Unit & 89-92 (n=1) & - \\
\hline Sango, Music shop & -- & Single Unit & $52-93(\mathrm{n}=8)$ & $66.0 \pm 13.6$ \\
\hline Sango vegetable market & -- & 1074 & $53-97(n=4)$ & $79.3 \pm 21.6$ \\
\hline Samonda saw mills & -- & A complex & $55-64(n=6)$ & $58.7 \pm 3.4$ \\
\hline Railway yard market & -- & -- & & \\
\hline
\end{tabular}

Table 2: Identified areas where noise levels exceeded permissible limits.

\begin{tabular}{|c|c|}
\hline Specific Area & $\begin{array}{c}\text { Noise Level } \\
\text { Db (A) }\end{array}$ \\
\hline Slaughtering area at Bodija market & 100 \\
\hline (Noise from people) & $93-100$ \\
\hline Music/Records Shop, Agbeni road side & $98-99$ \\
\hline Petrol Station generator (15 KV, <2m away), Bodija market & 97 \\
\hline Log cutting, Bodija market & $96-97$ \\
\hline Plack making machine (cement in it), Bodija market & $95-97$ \\
\hline Plank cutting machine, on but no plank in it, Bodija market & $88-95$ \\
\hline Grinding area, Ojo market & $94-95$ \\
\hline Pepper grinding machine, Sango market & 93 \\
\hline Maize grinding machine, Bodija market & $90-92$ \\
\hline
\end{tabular}




\section{Civil Engineering Research Journal}

\begin{tabular}{|c|c|}
\hline Music shop, Sango market & $89-92$ \\
\hline Petrol Station generator > 3 m away, Bodija market & $89-90$ \\
\hline Vulcanizers' air pump, Bodija market & $83-90$ \\
\hline
\end{tabular}

The identified areas where the noise levels are more than the permissible limits are given in Table 2 . The slaughtering area in Bodija market has the highest level followed by the electronics selling areas in Agbeni. In Bodija, about 300 cows are manually slaughtered every day from early hours of morning till late in the afternoon. Here, manual labour is used in bringing the cows to the place and in the slaughtering process. The sale of electronics and musicals are generally on the roadside and to attract the passersby, the traders play loud music. Other areas where the noise levels are above the permissible limits were woodcutting, block making, grinding, petrol generators, and vulcanizing areas. The activities that contribute to higher noise levels are given in Table 3. Loading, unloading, grinding, cutting, sawing, tailoring, and cement block making are some of the activities that contribute to higher noise levels. Noise levels at the access roads and the road junctions are given in Table 4. The minimum recorded was $53 \mathrm{~dB}$ and the maximum was $86 \mathrm{~dB}$. Some markets particularly [4].

Table 3: Various Activities that Contribute To Higher Noise Levels in the Markets.

\begin{tabular}{|c|c|}
\hline Activity & Noise Level, Db (A) \\
\hline Unloading goods in the market & $65-72$ \\
\hline Loading wood planks & $72-75$ \\
\hline Plank cutting operation & $95-97$ \\
\hline Log cutting & 97 \\
\hline Vulcanizing & 89 \\
\hline Maize grinding & $90-92$ \\
\hline General grinding (dry) & $94-95$ \\
\hline Yam flour grinding & $70-75$ \\
\hline A flour mill (small scale) & $86-88$ \\
\hline Pepper grinding (wet process) & $80-93$ \\
\hline Small scale grinding (5 in operation) & $85-87$ \\
\hline Block making machine in operation & $96-97$ \\
\hline Cash machine operation & 63 \\
\hline Tailoring & $80-81$ \\
\hline 1 machine in use & $84-85$ \\
\hline 4 machines in use & $76-77$ \\
\hline 5 machines in use & \\
\hline
\end{tabular}

Table 4: Noise Levels at The Road Junctions and Access Roads to Markets.

\begin{tabular}{|c|c|}
\hline Roads / Junctions & Noise Level, Db (A) \\
\hline Bodija market & 65 \\
\hline Entry to market, With no cars & $70-75$ \\
\hline With cars & $65-66$ \\
\hline Near petrol station & $73-75$ \\
\hline Near vegetable market & $68-75$ \\
\hline A side major road & $65-70$ \\
\hline Unloading area & $63-66$ \\
\hline Mokola market, & $63-73$ \\
\hline Side entry road & 83 \\
\hline Front entry road & $60-64$ \\
\hline Police van with siren & $55-58$ \\
\hline Railway yard area & \\
\hline Dugbe market junction & \\
\hline
\end{tabular}




\section{Civil Engineering Research Journal}

\begin{tabular}{|c|c|}
\hline Alesinloye market side road & 53-58 \\
\hline Kingsway / Adonis shops, Main road & $58-62$ \\
\hline Methodist area, main road & $70-74$ \\
\hline Agbeni main road & $60-65$ \\
\hline At a junction & $64-72$ \\
\hline End of the road / market & 53-58 \\
\hline Mapo Hall junction & 54-58 \\
\hline Oje fruit market, entry road & $55-60$ \\
\hline \multicolumn{2}{|l|}{ Agodi market area } \\
\hline Taxi park & $60-65$ \\
\hline Traffic junction & $55-60$ \\
\hline Near post office & $60-65$ \\
\hline \multicolumn{2}{|l|}{ Iwo Road area } \\
\hline No traffic & 65 \\
\hline Heavy truck moving & 78 \\
\hline Water tanker moving & 78 \\
\hline Mary Hill School junction & $70-75$ \\
\hline \multicolumn{2}{|l|}{ Faleye automobile market area } \\
\hline Salvation Army road junction (with traffic) & 70-74 \\
\hline Salvation Army road junction (without traffic) & $60-64$ \\
\hline A 4-road junction near AGIP petrol station & $70-75$ \\
\hline Load carrier trolley & 80 \\
\hline Idikan market area & $69-77$ \\
\hline \multicolumn{2}{|l|}{ Oke Ado area } \\
\hline Ogunpa - Oke-Ado & $65-80$ \\
\hline Odusote bookstore area & 66-71 \\
\hline Foko road junction & $66-72$ \\
\hline Isale-Ijale area & $65-72$ \\
\hline \multicolumn{2}{|l|}{ Oja-Oba market area } \\
\hline No traffic & $76-80$ \\
\hline With car horn & 83-85 \\
\hline Challenge, market area & 63-77 \\
\hline Ring road area & $65-78$ \\
\hline \multicolumn{2}{|l|}{ Apata market area } \\
\hline With traffic & 76 \\
\hline A tipper reversing & 81 \\
\hline A scooter & $72-74$ \\
\hline Main road junction & $79-86$ \\
\hline Petrol tanker moving & 78 \\
\hline \multicolumn{2}{|l|}{ Cocoa House complex } \\
\hline Main road & $65-72$ \\
\hline Main junction & $69-75$ \\
\hline \multicolumn{2}{|l|}{ Shasha market area } \\
\hline Unloading area & $68-72$ \\
\hline A Truck accelerating & $74-80$ \\
\hline
\end{tabular}




\section{Civil Engineering Research Journal}

\section{References}

1. Vagale LR (1972) Anatomy of Traditional Markets in Nigeria: Focus on Ibadan City, An occasional Publication from The Ibadan Polytechnic, Ibadan, pp. 1-38.

2. Filani MO, Iyun BF (1994) Markets, in "Ibadan Region". In: Filani MO, Akintola FO, Ikporukpo CO (Eds.), Ibadan, pp. 168-178.

This work is licensed under Creative Commons Attribution 4.0 License DOI: 10.19080/CERJ.2017.02.555597
3. Anon (1996) Plagued by noise, New Scientist, p. 14.

4. Federal Environmental Protection Agency (1991) Guidelines and Standards for Environmental Pollution and Control in Nigeria, pp. 6768.

\section{Your next submission with Juniper Publishers} will reach you the below assets

- Quality Editorial service

- Swift Peer Review

- Reprints availability

- E-prints Service

- Manuscript Podcast for convenient understanding

- Global attainment for your research

- Manuscript accessibility in different formats

( Pdf, E-pub, Full Text, Audio)

- Unceasing customer service

Track the below URL for one-step submission https://juniperpublishers.com/online-submission.php 